\title{
Tıp Tarihinde Tedavi Yöntemi Olarak Kullanılan Alçı: Doğada Hazırlanan Ev Yapımı
}

\author{
Alçı ${ }^{*}$ \\ Plaster Used as a Treatment Method in the History of Medicine: Home Made Form of Plaster Prepared in \\ the Nature \\ Hacer Çetini, Emel Yürük Bali \\ ' Doç.Dr., Mersin Üniversitesi Hemşirelik Fakültesi, Çocuk Sağlığı ve Hastalıkları Hemşireliği \\ https://orcid.org/0000-0002-3492-9307 \\ iiUz. Hem., Çukurova Üniversitesi Doktora Öğrencisi, Çukurova Üniversitesi Sağlık Bilimleri Enstitüsü Çocuk Sağlığı ve Hastalıkları AD \\ https://orcid.org/0000-0002-6984-133X
}

öz

Alçı uygulaması, vücut bölümlerini özel pozisyonda tutmak ve yumuşak dokuya eşit miktarda basınç uygulamak amacıyla uygulanmaktadır. Sırt, bel, eklem ağrılarında destek amaçlı, kırıklarda, kas ve lif zedelenmelerinde doku tespiti için sıklıkla alçı uygulamasına gereksinim duyulmaktadır. Anadolu sağıı kültüründe, sağlığa etkilerini ortaya çıkarmak amacıyla ev yapımı alçı uygulamasıyla ilgili bu çalışma yapılmıştır. Araştırma örneklemine şehre uzak dağ köylerinde yaşayan, 60 kişi ve 3 halk iyileştirici alınmıştır. Araştırma görüşme ve gözlem teknikleri kullanılarak nitel bir araştırma deseninde yapılmıştır. Ev yapımı alçı uygulaması sırasında altı grup ve ev yapımı alçı uygulanmasından sonra 3.-5. günlerde altı grup görüşmesi yapılarak araştırma verileri toplanmıştır. Bireyler araştırmaya gönüllü katılmışlardır. Araştırma için onamları alınmıştır. Ev yapımı alçı yapılanların bu uygulamayı sağlık kuruluşuna uzak oldukları, hemen rahatlamak istedikleri, ağrılarını azalttığı ve zararının olmadığını düşündükleri için dokuyu sabitlemek amacıyla yaptırdıkları ortaya çıkmıştır. Araştırmaya katılanların \%91.67'sı ağrılarının aynı günde azaldığını ve rahatladıklarını belirtmişlerdir. Evde yapılan alçı, ağrıyı azaltmada, anatomik yapıyı korumakta evde anneler ve halk arasında iyileştirici olarak bilinen halk ebeleri tarafından hazırlanarak uygulandığı günümüzde de belirlenmiştir.

Anahtar sözcükler: Alçı, ev yapımı alçı, doku sabitleyici, bakım

\section{ABSTRACT}

Plaster application is applied to keep body parts in a special position and to apply equal pressure to soft tissue. Plaster application is often required for tissue fixation in the cases of back, waist, joint pain, fractures, muscle and fiber injuries. In the Anatolian health culture, this study has been carried out on homemade plaster application in order to reveal the health effects. The sample of the study included 60 people and 3 people who were living in remote mountain villages. The research was conducted in a qualitative research design using interview and observation techniques. During the implementation of the homemade plaster, six groups and 3 to 5 after the application of homemade plaster. In the sixth day, research data were collected. Individuals were volunteers. Their consent was obtained for research. It was found that those who made homemade plaster made this application to get away from the health institution, wanted to relax immediately, reduced their pain and did not have any harm to fix the tissue. $91.67 \%$ of the participants stated that their pains decreased on the same day and they were relieved. Plaster made at home, pain relief, to protect the anatomical structure home mothers and the people known as the healing of the midwives by the popular midwives have been determined by the application today.

Key words: Plaster, home made plaster, tissue stabilizer, care

*Lokman Hekim Dergisi, 2019; 9 (1): 105-114

DOI: $10.31020 /$ mutftd.485119

e-ISSN: $1309-8004$

Geliş Tarihi - Received: 19 Kasım 2018; Kabul Tarihi - Accepted: 22 Ocak 2019

Iletişim - Correspondence Author: Emel Yürük Bal < emelyurukbal@gmail.com> 


\section{Giriş}

Dokuların iyileşmesine destek sağlamak üzere kullanılan alçının hammaddesi; doğada alçıtaşı olarak bilinen mineralli jips taşıdır. Jips/alçı taşının kimyasal bileşimi CaSo4+2H2O'dır. Yapı malzemesine dönüştürmek için, jips taşı yarım molekül kristal suyu kalacak şekilde kızdırılmaktadır. İşlem sırasında suyunun uçurulması ile elde edilen malzeme su ile karıştırıınca katılaşarak bağlayııılık özelliği kazanmaktadır. ${ }^{1}$

Günümüzden 8.800 yıl önce, alçının binalarda yapı malzemesi olarak kullanımına rastlamak mümkündür. Konya Çatalhöyük'te yapılan kazılarda evlerin zemininde ve duvarlarında alçı malzemesinin kullanıldığı tespit edilmiştir. Daha sonra Anadolu'da ve Mezapotamya'da, Sümer, Asur, Selçuklu ve Osmanlıda alçının kullanıldığı görülmüştür. Tarih boyunca olduğu gibi günümüzde de alçı yapı malzemesi olarak kullanılmaya devam etmektedir. ${ }^{1-3}$

Sağlamlığı nedeniyle alçı yapı malzemesi olarak, İngiltere ve Fransa'da 1666 -1700 yıllarda tercih edilmiştir. Zaman içinde yer fıstığı, pamuk, patates, gibi ürünlerle kalsiyum ve kükürt desteğiyle daha sağlamlaştırılarak alçı taşının kullanıldığı saptanmıştır.

Osmanlı döneminde yapılan araştırmalarda alçı kullanımı ile ilgili ilginç bilgilere rastlanılmıştır. Geçmişte Osmanlı Hamamlarında, alçının tavanda nemi dengelemek için kullanıldığı fark edilmiştir. Bunun dışında han ve kervansarayların mimarisinde, saray ve yalıların süslemesinde de alçı kullanılmıştır. ${ }^{1,3}$ Cumhuriyet döneminde Kayseri'de alçı üretmek için atölyeler açılmış ve çeşitli amaçlarla kullanımı artarak yaygınlaşmıştır. ${ }^{4,5}$

Sonraki yıllarda alçının kullanımı ile ilgili kültür 100'den fazla ülkede yaygınlaşmıştır. Şimdilerde 100 milyon tonun üzerinde alçıtaşı insanlar tarafından tüketilmektedir. ${ }^{2}$ Farklı amaçla kullanılan alçının, sağlık amaçlı kullanımı da oldukça yaygındır. ${ }^{2,5}$

\section{Sağlık amaçlı alçı uygulamasının nedenleri ise;}

- Anatomik bütünlüğünü sağlamak üzere kırık kemikleri desteklemek,

- Kırıkların hareketliliğini kontrol altına alarak iyileşmesini hızlandırmak,

- Hasar görmüş yumuşak dokuların sabitlenmesi ile dinlenmesini sağlamak,

- Ligamentöz yaralanmalardan sonra ekstremitenin sabitlenmesi ve dinlendirilmesini sağlamak,

- Eklemlere ve ekstremitelere yapılan ameliyat sonrası, iyileşme olana kadar eklem ve ekstremitelerin desteklenmesi ve sabitlenmesiyle dokunun yara iyileşmesini hızlandırmak,

- Enfekte olmuş dokuların dinlendirilmesini sağlayarak enfeksiyonu sınırlayıp, iyileşmeyi daha da hızlandırmaktır. ${ }^{6,7}$

\section{Sağlık amaçlı olarak alçı uygulamasının avantajları}

Alçı uygulamasının yapılması çok kolaydır. Alçı ucuzdur, dayanıkıdır (aylarca verilen şekilde bozulmadan kalır). Uygulandığı organın şeklini alır, alçıya uygulandığı yere göre istenilen şekil verilebilmektedir. Alçı röntgen ışınlarına geçirgen olduğundan, alçılanan ekstremitelerin-kemiklerin röntgeni çekilerek kontrol edilebilir. Açık kırıklarda ya da ekstremite ameliyatlarında yara kontrolü için alçıda kolaylıkla pencere açılarak dokuda iyileşme ve gelişmeler izlenebilir. ${ }^{3,8}$ 


\section{Sağlık Amaçlı Uygulanan Alçı Çeşitleri}

\section{Dairevi Alçı (Sirküler Alçı)}

Kol, bacak gibi vücut bölümlerinin çepeçevre alçıyla dairevi olarak sarılması dairevi alçı olarak adlandırlmaktadır. Alçının tümü biraz düzensiz olan silindir görüntüsüne benzediği için silindirik alçı adı da verilmektedir. ${ }^{9}$ En çok kullanılan alçı uygulama biçimidir.

\section{Sentetik Alçılar}

Sentetik alçılar, normal alçıya göre daha hafif, daha sağlam, röntgen ışınını tamamen geçirdiğinden ve görüntüsü daha zarif olduğu için, hatta çocuklar için değişik renklerde bulunduğundan son yıllarda daha çok kullanılmaktadır. Bu alçının diğer avantajları; alçının ıslatılabilmesi ve ağılık taşıma, kuruma beklenmeden kısa bacak yürüme alçısı ile hemen başlanılabilmesidir. ${ }^{10}$

Sentetik alçı, istatistiksel olarak daha yüksek bir sağlamlık derecesine ve performansa sahip olmasıve kolay çıkarılabilme özelliğiyle ile uygulamalarda tercih edilmektedir. ${ }^{7}$

\section{Bugün, alçılamada en çok kullanılan sentetik materyaller:}

- polyester/pamuk örme

- termoplastikler

- fiberglas

- fiberglas içermeyen polimerler. ${ }^{11}$

\section{Alçı Uygulama Basamakları}

Dokuların iyileşmesi için destek ve tespit materyali olarak alçı, günümüzde sağlık alanında kullanılmaya devam etmektedir. Alçı uygulaması konusunda başlangıçta, birey bilgilendirilir ve bilgilendirilmiş onamı alınır. Alçı uygulaması sırasında öncelikli olarak, destek materyali tam olarak hazırlanmalı, hasta bireyin dokusunun bütünlüğü ve anatomik pozisyonu korunmalıdır. Hastanın konforunu sağlayacak desteklemeler yapılmalı, dokuların alçı sarılması/uygulaması sırasında dolaşımı engellenmemelidir. Alçı uygulaması sırasında hasta bireyin zarar görmesini engelleyecek biçimde, alçının altında kalan dokunun üstü, alçının altından koruyucu materyalle önceden sargılanmalıdır. Alçı uygulanacak bölgenin üstünde başlanan alçılama işlemi, tespiti istenen bölgenin altında ve üstündeki eklemlerin hareketini kısıtlayarak, doku sabitlemesini yapabilmelidir. Alçı çok sıkı ya da gevşek sarılmamalıdır. Fonksiyonel olmasını sağlayacak bir uygulama olmasına dikkat edilmelidir. Alçı uygulanırken elle ve parmaklarla alçı tutturulmaz. Aksi halde dokulara zarar veren alçı çökmeleri oluşabilir. Sonuçta bu çökmeler, dokuda basınca ve zedelenmelere yol açabilir. Alçı ekstremitelere uygulandığında el ve ayak parmakları açıkta kalacak şekilde sarılmalıdır. Alçının kendiliğinden kuruması ortam sıcaklığında sağlanmalı, üzeri örtülmemelidir. Alçıyı kurutmak için ek sıcaklık sağlamak sakıncalıdır. ${ }^{10,12-16}$

Alçıdan sonra açık bırakılan parmakların rengi, sıcaklı̆̆ı, hareketi ve hassasiyeti kontrol edilmelidir. Başlangıçta ilk bir saatte 15 dakikada, daha sonraki saatte her yarım saatte, üçüncü saatten sonra saatlik gözlem yapılır. Daha sonra her 4 saatte bir nöromüsküler kontrol sağlık profesyonelleri özellikle hemşireler tarafından yapılmaktadır. Hasta eve gideceği zaman, bu kontrol aileye ve bakım verecek kişilere de anlatılmalıdır. ${ }^{17-19}$ 


\section{Doğada Hazırlanan Alçı Formu: Ev Yapımı Alçı}

Profesyonel uygulamaların dışında alçı uygulaması, geleneksel olarak evde yukarda bahsedilen materyallerden farkı olarak halen günümüzde uygulanabilmektedir. Halk kendi kullandığı, bulduğu, öğrendiği malzemelerden alçı yaparak doku sabitleyicisi, destekleyicisi olarak alçıyı kullanmaktadır. Ev yapımı alçı; bel, sırt, eklem, bilek burkulmaları, kas ve doku zedelenmelerinde doktora gidinceye kadar, doktora gitmek istemeyenlere, doktora gidip sorunu çözümlenemeyip ağrısı devam edenlere, ilk yardım ve ağrıyı azaltııı olarak kullanılmaktadır. Anadolu sağlık kültüründe yüzyıllardan beri sorun yaşanılan bölgelerin tespiti için yumurta ve sabun, doğal tespit materyali olarak kullanılarak dokunun sabitlenmesinde kullanılagelmiştir. Bu alçı yapıldığında; ağrıyı azaltmakta ve anatomik yapıyı korumaktadır. Bu nedenle alçı, bakımda hızlı rahatlatmayı sağlamak, doktora gidinceye kadar ya da gitmeden çözüleceği düşünülen sağlık sorunlarında bakım materyali olarak kullanılmıştır. Yumurta ve sabun ile hazırlanan bu materyalin evde anneler ve halk arasında iyileştirici olarak bilinen halk ebeleri tarafından hazırlanarak uygulandığı günümüzde de halen görülmektedir.

\section{Doğada Hazırlanan Alçı Formu; Ev Yapımı Alçının Hazırlanışı}

Halk iyileştiricileri ve anneler tarafından evde hazırlanan ve doku sabitlemede kullanılan ev yapımı alçının hazırlanışı şu şekildedir: Bir adet yumurtanın içine kıvamı sertleşene kadar saf zeytinyağı ile yapılmış beyaz/yeşil sabun rendelenerek ilave edilir. Sonra karışım beyaz temiz bir bezin üzerine dökülür. Alçı gibi sertleşmesi için hafif güneşte ya da oda sıcaklığında (24-28 $\left.{ }^{\circ} \mathrm{C}^{\prime} \mathrm{de}\right)$ bekletilir. Uygulanacak bölgeye gereksinim duyulursa evde bulunan tülbent benzeri materyalle evde hazırlanan alçı sarılarak kapatılır. İşlem sonrasında bu sabitlenen ev yapımı alçının dokuda en az üç gün boyunca kalması istenmektedir. Ev yapımı alçıda kullanılan malzemeler ve hazırlanışı aşağıdaki fotoğraflarda görülmektedir (Şekil 1-7). Bu fotoğraflar araştırma sırasında gözlem ve görüşmelerde çekilmiştir.

Bu çalışmada halk arasında yaralanmalar ve incinmelerden sonra evde yaptıkları alçıyı anlatanlardan yola çıkılarak halk uygulamasının ortaya çıkarılması hedeflenmiştir.

\section{YÖNTEM}

\section{Araştırma soruları}

Halk arasında geleneksel olarak evde yapılan alçının uygulanma şekli ve sonuçları uygulayanlar, uygulananlar ve sağlık profesyonellerince bilinirse, yapılan uygulamaların yararı ya da olabilecek zararı var mı? bilinmesi gereklidir. Halkın/halk iyileştiricilerin uyguladığı ve uzun yıllardır yapılan ilk yapanı bilinmeyen ev yapımı alçı hangi durumlarda nerelerde uygulanmaktadır? Bu uygulamadan herhangi bir zarar gören olmuş mudur? Zararları nelerdir? Evde yapılan alçı ne zaman uygulanmaktadır? Bu sorularla araştırma başlamıştır. Şunlar elde edilmiştir.

\section{Ev yapımı alçı ve uygulandığı yaralanma durumları}

Ev yapımı alçı; bel, sırt, eklem, bilek burkulmaları, kas ve doku zedelenmelerinde doktora gidinceye kadar, doktora gitmek istemeyenlere, doktora gidip sorunu çözümlenemeyip ağrısı devam edenlere, ilk yardım ve ağrıyı azaltıcı olarak evde alçı hazırlanabilmektedir. Anadolu sağlık kültüründe yüzyıllardan beri yukarda bahsedilen sorunlara benzer sorunlar yaşandığında, bakımda erken yardım ve iyileştirici özelliği nedeniyle; sorun yaşanılan bölgelerin tespiti için yumurta ve sabun, doğal tespit materyali olarak kullanılarak dokunun sabitlenmesinde kullanılagelmiştir. Bu alçı yapıldığında; ağrıyı azaltmak da ve anatomik yapıyı korumaktadır. Bu nedenle bakımda hızlı rahatlatmayı sağlamak, doktora gidinceye kadar ya da gitmeden çözüleceği düşünülen sağıık sorunlarında bakım materyali olarak kullanılmıştır. Bu materyali evde anneler ve halk 
arasında iyileştirici olarak bilinen halk ebeleri tarafından hazırlanarak uygulandığı günümüzde de halen görülmektedir.

\section{Doğada Hazırlanan Alçı Formu; Ev Yapımı Alçının Hazırlanışı}

Halk iyileştiricileri annelerden alınan ev de ev yapımı alçı yapımı söyle olmaktadır. Evde doku sabitlemede kullanılan ev yapımı alçııın hazırlanışı şu şekildedir. Bir adet yumurtanın içine kıvamı sertleşene kadar saf zeytinyağı ile yapılmış beyaz/ yeşil sabun rendelenmektedir. Kıvamı sertleşene kadar sabun rendelenerek ilave edilmektedir. Sonra karışım beyaz temiz bir bezin üzerine dökülmektedir. Alçı gibi sertleşmesi için hafif güneşte ya da oda sıcaklığında $\left(24-28{ }^{\circ} \mathrm{C}^{\prime}\right.$ de) bekletilmektedir. Uygulanmak için hazırlandı ise o bölgeye gereksinim duyulursa evde bulunan tülbent benzeri materyalle evde hazırlanan alçı sarılarak kapatılmaktadır. İşlem sonrasında bu sabitlenen ev yapımı alçının dokuda en az üç gün boyunca kalması istenmektedir. Ev yapımı alçıda kullanılan malzemeler ve hazırlanışı aşağıdaki fotoğraflarda görülmektedir. (Şekil 1-7). Bu fotoğraflar araştırma sırasında gözlem ve görüşmelerde çekilmiştir.
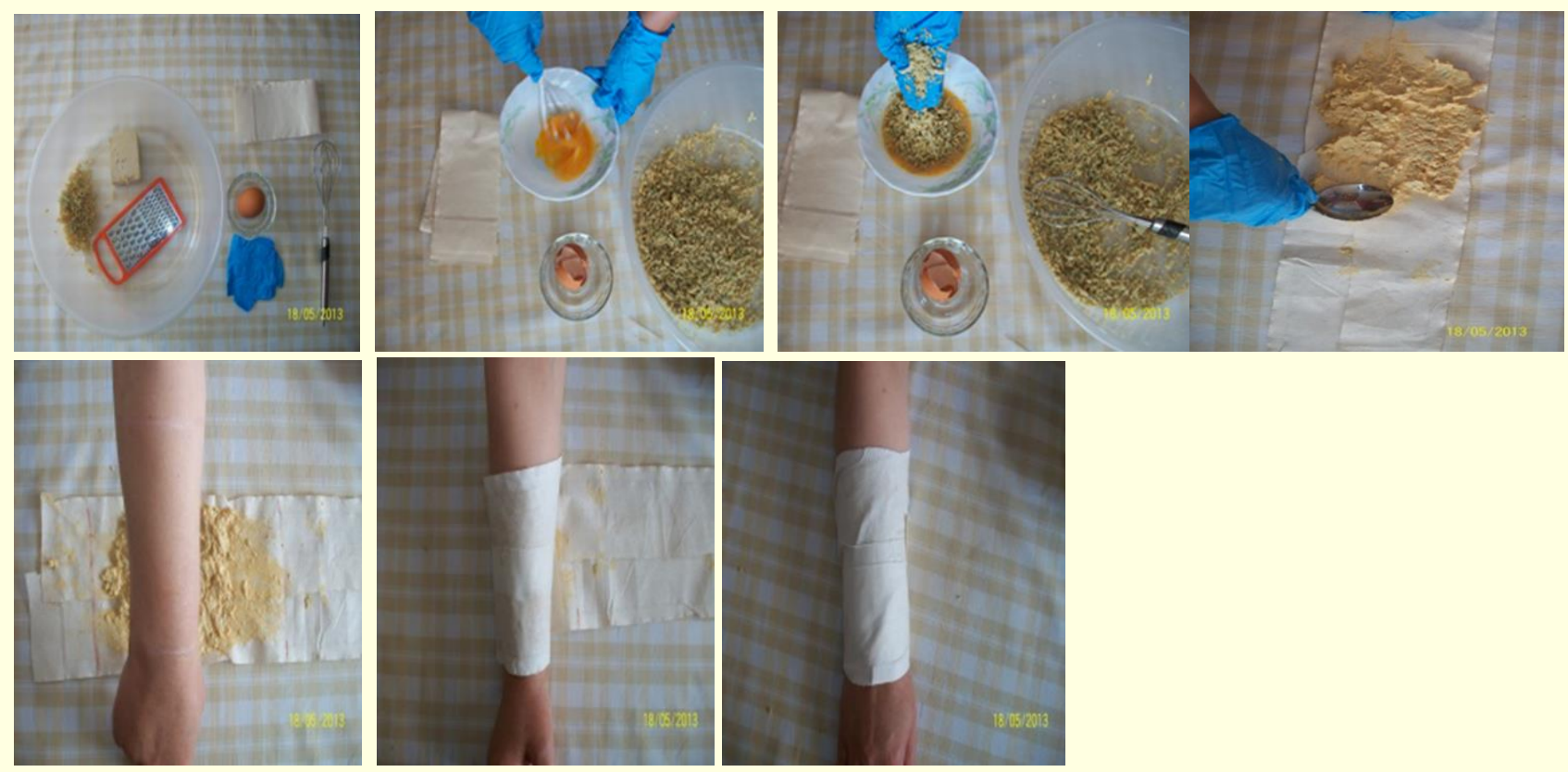

Şekil 1-7. Doğada Hazırlanan Alçı Formu: Ev Yapımı Alçı”nın uygulanışı (Fotoğraflar Emel Yürük Bal tarafından işlem yapılırken izin alınarak çekilmiştir)

\section{Araştırmanın evren ve örneklemi}

Araştırma evrenini; şehir merkezine uzak 6 köy ve yayla içerisinde evde alçı uygulamasını yapan üç halk iyileştiricisi ve uygulamayı yaptıranlar oluşturmuştur. Bu köyler şimdi mahalle olarak değerlendirilse de hala halk yaşantısı köy düzeyindedir. Köyün şehre uzak oluşu, araç olmaması gibi nedenlerle, yaralanan bireylerin istedikleri anda sağlık kuruluşlarına ulaşımı yeterince sağlanamamaktadır. Bu köylerin nüfusu 4504500 arasında değişmektedir. Ev yapımı alçı uygulaması daha çok kadınlara, çocuklara ve nadiren erkeklere uygulanmaktadır. Ev yapımı alçının uygulandığı durumlar; bel, sırt, eklem, bilek burkulmaları, kas ve doku zedelenmesi, kapalı yaralanma, eklem ağrısı ve hareket kısıtlılı̆ı̆dır. Bu uygulamaları yapan üç halk iyileştiricisi ve onlardan hizmet aldığı saptanan ve bilgilendirildikten sonra araştırmaya gönüllü katılmayı kabul eden 12 ayrı grup görüşmesi yapılan toplam 60 kişi araştırma örneklemini oluşturmuştur. Bunların yaşı 12- 60 yaş arasındadır. Kendilerine yapılan uygulamayı kendileri kabul ederek yaptırmışlardır. Bunların 30’u 19-60 yaş grubu kadın, 20'si 12-18 yaş (12 kız, 8 erkek çocuk) grubunda çocuk ve 10'u 19-60 yaş arası 
erkektir. Araştırma bulguları, araştırma konusunda bilgilendirildikten sonra, araştırmaya gönüllü katılan toplam 60 kişiden toplanmıştır.

\section{Veri Toplama Aracı ve Verilerin Toplanması}

Araştırma sırasında 12 ayrı grup görüşmesi yapılmıştır. Evde doku sabitlemede kullanılan alçının etkilerini gözlemlemek üzere yapılan bu araştırmada, araştırma soruları görüşme soruları olarak kullanılmıştır. Araştırma sırasında ev yapımı alçı uygulaması yapılan kişilerin dokuları ve ergonomik hareketleri gözlemlenmiştir. Araştırma raporları bu araştırma tekniklerine göre oluşmuştur.

Gözlemler, alçı uygulaması yapılan katılımcıların ve halk iyileştiricilerinin evlerinde görüşme sırasında yapılmıştır. Bireylerin verdiği yanıtlar ve gözlemler araştırmacılar tarafından rapor haline getirilmiştir. Gözlem sırasında araştırmacı gözlem alanlarında halk iyileştiricilerini ve katılımcıları görebileceği bir yere oturarak, alçı uygulama işlemini ve uygulama sonrası etki/yan etkilerini bir saat boyunca not alma yöntemi kullanarak toplamıştır. Evde alçı uygulaması gerçekleştirilen kişiler ( $n: 60)$ ile alçı uygulamasının hemen sonrasında altı odak grup görüşmesi yapılmıştır. Ev yapımı alçı uygulamasından 3-5 gün sonra, bu kişilerle bir köy evinde toplanarak altı odak grup görüşmesi yapılmıştır. Bu odak grup görüşmelerine iş yoğunluğu ve okulda olmaları nedeniyle 10 erkek ve beş çocuk katılımcı katılamamışlardır. Uygulama sonrası değerlendirme görüşmeleri bu yüzden yine altı grup halinde, ancak 45 kişi ile yapılmıştır. Her görüşme toplam 20 dakika sürmüş ve katılımcılardan izin alınarak ses kaydı yapılmıştır. Halk iyileştiricileri ile görüşmeler ise evde alçı uygulaması yaptığı işlem esnasında yapılmıştır. Bu görüşmelerde katılımcılara "evde alçı uygulamasına nasıl karar verdikleri", "sağılık sorunlarının ne olduğu", "alçı uygulamasından sonra, kendilerini nasıl hissettikleri ve başka işlem yapıp yapmadıkları", "yapılan ev yapımı alçının bir yan etkisi olup olmadığı" ve "ev yapımı alçının etkileri ve faydalarının neler olduğu" nu ilişkin sorular yöneltilmiştir.

\section{Verilerin Analizi}

Gözlem ve görüşme yoluyla not alma ve ses kaydıyla elde edilen veriler araştırmacılar tarafından çözümlenerek ham dökümü yapılarak raporlanmış, daha sonra betimsel analiz yapılmıştır. Analizin ilk aşamasında toplanan veriler araştırmacı tarafından kodlanmış ve araştırma konusu hakkında genel bilgiye sahip ve nitel araştırma yöntemleri konusunda uzman bir araştırmacı tarafından bu kodlar incelenmiştir. Araştırma verilerinin analizinde birbirine benzeyen kavramlar ve temalar gruplandırılmış; "evde alçıyı yapımı", "Evde yapılan alçının uygulanma nedenleri", "işlem öncesi şikayetler", "işlem sonrası durum", "yan etki görülme durumu" "halkın başvurma gerekçeleri" başlıklarında toplanmıştır. Bu verilerin analiz edilmiş halini Tablo 1'de bulgularda yer almıştır.

Elde edilen bulguların kendi içinde anlamlı ve tutarlı olup olmadığını incelemek üzere; benzer kodları belirli ortak temalar altında toplama sürecinde araştırmacı ile uzman araştırmacı fikir alışverişinde bulunmuşlardır. Sonuçta bu araştırma sürecinde etik kurallara uygun olarak çekilen fotoğraflarda bireysel tanınmayı gizlemeye özen gösterilmiştir. Tablo1'de araştırmayı en özetleyecek bilgilerle sunulmuştur. 
Tablo 1. Ev yapımı alçı uygulatma nedenleri, işlem öncesi şikayetler, işlem sonrası durum, yan etki görülmesiyle ilgili sonuçların dağılımı

\begin{tabular}{|c|c|c|c|}
\hline $\begin{array}{l}\text { Ev yapımı alçı uygulama } \\
\text { nedenleri ( } n, \%)\end{array}$ & İşlem öncesi şikayetler & İşlem sonrası durum & Yan etki \\
\hline Belde ağrı $(15, \% 25)$ & Ağrı var & Ağrı 24 içinde azaldı & Görülmedi \\
\hline $\begin{array}{l}\text { El ekleminde incinme } \\
(10, \% 16.67)\end{array}$ & Hareket kısıtlı, ağrı var & Ağrı 24 saat içinde azaldı & Görülmedi \\
\hline $\begin{array}{l}\text { Düşme sonrası sırtta ağrı } \\
(5, \% 8.33)\end{array}$ & Ağrı var & $\begin{array}{l}\text { Hareket kısıtlılığı } 2 \text { gün azaldı } \\
\text { Ağrı } 24 \text { saatte kesildi }\end{array}$ & Görülmedi \\
\hline Dokuda renk değişikliği ödem & Kızarıklık, hassasiyet, & & $\begin{array}{l}\text { Ağrı hassasiyet yok. Dokuda } \\
\text { ezilmeye bağlı hafif morluklar } \\
\text { (ekimoz) var. }\end{array}$ \\
\hline $\begin{array}{l}\text { Eklem hareketlerinde kısıtılık } \\
(20, \% 33.33)\end{array}$ & Hareket kısıtlı & Ağrı 3. gün kalmadı & Görülmedi \\
\hline $\begin{array}{l}\text { Başka bir işlem yapılması } \\
\text { gerektiği }(10, \% 16.67)\end{array}$ & $\begin{array}{l}\text { İşlem sırasında aldığı } \\
\text { pozisyonu bir süre } \\
\text { koruması istendi }\end{array}$ & & $\begin{array}{l}\text { Ağrısı geçmeyen } 5 \text { kişi sağlık } \\
\text { kuruluşuna ulaşım öncesi doku } \\
\text { sabitlendiğinden "yan etkinin } \\
\text { önlendiğinin" sağlık } \\
\text { personelince belirtilmiş olduğu } \\
\text { ifade edildi }\end{array}$ \\
\hline
\end{tabular}

\section{BULGULAR}

\section{Gözlem Yoluyla Elde Edilen Alçı Uygulamasına ílişkin Bulgular}

Evde alçı uygulaması gerçekleştirilen kişiler işlem sırası ve sonrasında gözlemlenmiştir. Ev yapımı alçı uygulaması esnasında, doku sabitlenirken anatomik yapının korunmasına özen gösterildiği gözlemlenmiştir. Ev yapımı alçı uygulaması sonrasında yapılan gözlemlerde, yaralanma olan bölge ve etrafındaki ödem ve kızarıkığın hızlıca dağıldığı, ayrıca uygulama sonrası herhangi bir enfeksiyon belirtisine rastlanılmamıştır.

Bazı bireylerde ise, bir sağılık kuruluşuna ulaşıncaya kadar geçen sürede bakım sırasında dokudaki ödemin çözülmesi, rahatsızlığın azalması ya da tamamen giderilmesi, eklem ve doku bütünlüğümün korunduğu gözlemlenmiştir

\section{Evde alçı uygulaması yaptıran kişilerin uygulamanın etkilerine dair görüşleri}

Evde alçı uygulaması yaptıran katılımcılar, çoğunlukla uygulamanın hemen sonrasında doku sabitlendiği için, ağrının kademeli olarak azaldığını (55 kişi, \%91.67) belirtmişlerdir. Uygulama süresinde ağrıda azalma ve tamamen iyileşme gerçekleşmiştir. Katılımcıların çoğunluğu (\%91.67), yayla ya da hastaneye uzak birimlerde yaşadıklarından doktor ya da hastaneye başvurmaya hazırlanırken rahatsızlıkları geçtiği için bir sağıı kuruluşuna gitmediklerini de ifade etmişlerdir.

Ev yapımı alçı uygulaması yapan halk iyileştiricileri uygulamanın ilk saatlerinde ağrı ve rahatsızlıkları geçmeyenlere "Hemen bu işlemden sonra rahatlamazsanız, doktora gidin. Başka sorun vardır" dediği için; ev yapımı alçı uygulaması sonrası ağrısı geçmeyen beş kişi (\%8.33) doktora gitmiştir. Doktora gidenlerden iki çocuğun "kapalı parçalı kırık", iki yetişkin de ağaçtan düşme sonrası "omuz çıkı̆̆ı" tanısı aldığı belirlenmiştir. Sağlık personelinin dokunun sabitlenmesini sağlayan bu işlemin dokunun daha fazla zarar görmesini engellediğini ifade ettiklerini katılımcılar belirtmişlerdir. 
Ev yapımı alçı uygulamasını yaptıran kişilerin tamamı "Biz bu halk iyileştiricilerine güveniyoruz, o bize zarar vermez." "Doktora gitmemiz gereken durumları da iyice bir anlatır, ayrıca tedavi masrafı da doktora gitmeye göre hiç yok gibi. Durumumuza göre ödeme yapıyoruz ya da yapmıyoruz. Tanıdık olduğundan küçük hediyelerle gönlünü alıyoruz. "O ücret talep etmiyor” ifadelerinde birleşmişlerdir.

İşlemin uygulanması sırasında malzemeleri işlemi talep edenlerin sağladığı gözlemlenmiştir. Evde alçı uygulatanlardan bir sorun olmazsa bu alçının 3-5 gün sarıldığı gibi kalması istendiği görülmüştür. Ev yapımı alçı uygulamasından 3-5 gün sonra yapılan odak grup görüşmelerinde, katılımcılar doku zedelenmesi olan bölgelerini göstermişler ve Tablo 1'de verilen işlem öncesi ve sonrası şikayetler ve ev yapımı alçı uygulamasının yan etkilerine ilişkin görüşlerini belirtmişlerdir. Ayrıca çalışmaya katılan halk iyileştiricileri de işlemin dokuya zarar vermediği için yapılmasında sakıncanın olmadığını belirtmişlerdir.

Aşağıda ev yapımı alçı uygulaması yaptıran kişilerin ve halk iyileştiricilerinin görüşleri yer almaktadır:

\section{Ev yapımı alçı uygulatanların ifadeleri}

- "Evde yapılan alçı uygulaması sonrası ağrım azaldı." (A)

- "Şişlik başladığından ve kızarıklık olduğu için hareket edemiyordum, fakat alçı sonrası şişlik indi"(A)

-"Evim sağlık kuruluşuna çok uzak ve aracım yok. Seher Teyze (halk iyileştiricisi) daha önceden kardeşimin ayağındaki kırığı bile iyileştirmişti. Biz küçüklüğümüzden beri ona gideriz. Alçı yaptığı yer tamamen iyileşir...." (B)

- "Hızı bir şekilde iyileşmek istiyorsanız, evde alçı uygulaması yapmalısınız. Eskilerden beri nenelerimiz ağrı dinsin diye bu malzemeleri karıştırıp güzelce sararlarmış...." (C)

- Halk iyileştiricisi: "Yumurta akı ve sabun sayesinde doku hızlıca sabitlenir. Böylece bölgedeki şişlik iner ve ağrı azalır. Bir hafta sonrasında alçı çıkartılıp kontrol edilir. Gerekirse yenisi yapılır. Hiçbir yan etkisi yoktur..."

-Halk iyileştiricisi: "Sabitlemeyi çok küçük yaşlarımda nenemden birçok kez görerek öğrendim. Eskiden bu yöntem ile birçok yaralı iyileştirilmiş. Çocuklar yaralandığı zaman hastaneye gitmek yerine ebelere getirilirmiş. Iç̧indeki bütün malzemeler doğal bir iyileştiricidirler. Ben öyle gördüm öğrendim.

\section{TARTIŞMA}

Şehirlere/sağlık kuruluşlarına uzak bölgelerde yaşayan halk, günümüzde halen basit doku zedelenmelerinde, halk iyileştiricilerine başvurmaktadır. Son yıllarda tamamlayıcı tıp uygulamaları giderek yaygınlaşmaktadır. Bu uygulamaların yapılma nedenlerini araştıran Akdeniz ve arkadaşları "sosyal kültürel faktörler, ulaşım sorunları, güvendiğin birinden daha ucuza ve kolay hizmet alma olduğunu belirtmişlerdir. ${ }^{20}$ Bu araştırma da ev yapımı alçı uygulatan katılımcıların benzer nedenlerle bu uygulamayı yaptırdıkları belirlenmiştir.

Ev yapımı alçı uygulamasına ilişkin benzer bir çalışmaya rastlanılmamıştır. Bu araştırma var olan bu uygulamanın ortaya çıkartılması amacıyla araştırılıp verileri toplanarak yapılııı̧tır.

Halkın kendisini anlayan, hemen ulaşabildikleri kişiye uygulama yaptırma eğilimlerinin daha yüksek olduğuna ilişkin birçok yayına ulaşılabilmektedir. ${ }^{20-23}$

Halk iyileştiricilerinin halka zarar vermeden, hatta yaralanmalarda doku hasarını azaltıcı uygulamalarla sağlık profesyonellerinin uygulamalarını kolaylaştırıcı ve doku hasarı yaşayan bireylerin daha az zarar görmelerini sağlayııı bu tür uygulamaların güncel olarak bilinmesi de faydalıdır. Bu fayda; "eğer uygulamalar zararlı ise ortadan kaldırıması konusunda halkla iş birliği ile sorunun çözümlenmesi", "eğer uygulamanın zararı yoksa 
halkın uygulamalarının tamamlayııı tıpta yararlı bir şekilde destekleyici bakımda kullanılabilirliğini kabul etmek" gibi uygulamalara ışık tutacağından önemlidir.

Bu araştırmada, halk iyileştiricilerinin uzun zamandan beri uyguladıkları doku sabitleyici olarak kullandıkları ev yapımı alçının açık olmayan yaralanmalarda, doku zedelenmelerinde uyguladıkları, ev yapımı alçı uygulatanların \%91.67'sinde bir yan etki görülmediği saptandığından bu araştırma örneklemi dahilinde bireylere zararı olmayan bir uygulama olduğu kanısı uyanmıştır. Ev yapımı alçıyı uygulamamak, uygulatmamak bireylerin tercihlerine bağlıdır.

\section{SONUÇ VE ÖNERILER}

Ev yapımı alçı uygulamasını yaptıran kişiler, genellikle o çevrede oturan, önceden uygulamayı yaptırmış kişileri tanıyan, iyileştirildiklerini gözlemleyen, aileden biri ya da yakın çevresinin önerisi ile, bu uygulamayı yaptırmaktadırlar. Böylece uygulamayı kimin nasıl başlattığı bilinmemekle birlikte, sonuçları başarılı olarak gözlemlendiğinden, yan etkileri de yaşanmadığından hala süregelmektedir. Bunların yanında halk iyileştiricisi olan kişiler, dokuda hasar büyükse bu işlemi yapamayacağını, hastanın cerrahi olarak ameliyat yapılması gerektiğini ifade ederek aileyi ve hastaları acilen sağılık kuruluşlarına yönlendirebilmektedirler. Bu şekilde bir tür triyaj yapan bu halk iyileştiricileri bu nedenle de güven oluşturduğundan tercih edilebilmektedirler. Ayrıca uygulamaları sırasında zarar gören bir vakanın ortaya çıkmadığı ev yapımı alçı uygulaması yaptıranlar tarafından ifade edilmiştir.

Ayrıca, ev yapımı alçı uygulaması uygulandığı sağıık sorununu rahatlatarak, bakımda, çözüme yardım ettiği gibi aynı zamanda yan etkisi hemen hemen hiç görülmemiş bir uygulamadır. Bu nedenle halk tarafından uygulanmasına izin verildiği de söylenebilir. Bu konu ve benzer konularda, halkın uygulamalarının ortaya çıkarılmasının, sağık profesyonellerince bilinmesi, yapılacak uygulamalara yön verilmesi, sağlık eğitimi ve uygulama planlamaları acısından değerli olduğu düşünülmektedir.

\section{BiLGi}

Bu çalışmanın geniş özeti, 03-05 Haziran 2013, Antalya'da düzenlenen II. Ulusal Kültürlerarası Hemşirelik Kongresi "Bakımımda Değerlerini Gözetiyorum"da poster bildiri olarak sunulmuştur.

\section{KAYNAKLAR}

1. Alturfan AK, ve ark. Ortopedik Travmatoloji., Nobel tıp Kitapevi, İstanbul; 2002. ss: 1-89.

2. Romed Alçı Pamugu 2006. Erişim tarihi: 25. 04. 2018. http://www.romed.com.tr/hastabakimvesarf.thm. (alçı pamugu).

3. Yavuz M. Ortopedi ve Travmatoloji., Cerrahi ders Notları, Izmir. 2001.

4. Ege R. Travmatoloji Kırıklar-Eklem Yaralanmaları., 4.Baskı, Kadıoglu Matbaası, Cilt 1, Ankara 1989; 4(1):3-604.

5. Ertem K, ve ark. Humerus Cisim Kırıklarında Tedavi Yöntemleri., Inönü Üniversitesi Tıp Fakültesi Dergisi 2004;11(1):15-17.

6. Erdemli B. Iskelet Sistemi Travmaları, Kırık ve Çıkıklar., Erişim Tarihi:17.04.2018.

http://Www.Medicine.Ankara.Edu.Tr/Surgical_Medical/OOrthopaedics/Turkish/Dersler/Bekirik.Htm.

7. Smith GD, Hart RG, Tsai TM. Fiberglass Cast Application., American Journal of Emergency Medicine, 2005 ; 23 (3): $347-35$.

8. Kılıçoglu S. Mikroskobi Düzeyinde Kırık Iyileşmesi. Ankara Üniversitesi Tıp Fakültesi Mecmuası 2002; 55(2): 143-150.

9. Gedikoglu G. Kırık iyileşmesi., Erişim Tarihi: 23.01.06 http://www.Medinfo.Hacettepe.Edu.Tr/Ders/TR/D3/9/3155.Pdf

10. Kramer L. Stock M. ve ark, (çeviri: Ünlü Ü.). Klinik Muayene Tanı, Tedavi, Acil Klavuzu Ortopedi.,Yüce yayınları, 2.Baskı 1994. ss:20-23.

11. McRAE R. Practical Fracture Treatment, Third Edition, ELBS With Churchill, Livingstone, 1995. ss. 4-96.

12. Adams J.C. Outline of Fractures., English Language Book Society/ Churchill Livinstone, Eight Edition, 1985. ss:4-49.

13. Brunner L., ve ark. Medical-surgical Nursing., sixth Edition, J.B. lippincott Company, Philadelphia, 1988. ss:1277-1285. 
14. Yücetürk G. Tıp Ögrencileri ve Pratisyenler için Ortopedi ve Travnatoloji. Saray Kitapevi, İzmir, 1997. ss:298-299.

15. Graeme A. Patients' Experiences of Hip Fracture, Journal of Advanced Nursing, 2003; 44(4):385-392.

16. Staheli L.(çeviri: Zorel, G). Pediatrik Ortopedinin Temelleri., Nobel Tıp Kitapevleri, 1988. ss. 13-21.

17. Çavuşoğlu H. Çocuk Sağlığı Hemşireliği, Kas İskelet Sorunu Olan Çocuk ve Hemşirelik Bakımı., Genişletilmiş 11. Baskı. I. Cilt, Sistem Ofset Basımevi, Ankara, 2013. ss.391-421.

18. Zeytinoglu M. Canlılarda hareket, Iskelet ve Kas Sistemi., Erişim Tarihi: 23.04.2018 http://www.aof.edu.tr/litap/ioltp/2281/unite 12.pdf.

19. Yürük Bal E, Çetin H. II. Ulusal Kültürlerarası Hemşirelik Kongresi“Bakımımda Değerlerini Gözetiyorum”., "Doğanın Bize Sunduğu İyileştiriciler; Evde Uygulanan Alçı”., Poster Bildiri, no: 38 (s.85)., Akdeniz Üniversitesi Hukuk Fakültesi Konferans Salonu., Akdeniz Üniversitesi Hemşirelik Fakültesi., 03-05 Haziran 2013, Antalya/ Türkiye.

20. Akdeniz $M$, ve ark. Geleneksel Halk Tedavilerinin Birincil Sağlık Bakımı Üzerine Etkisi: Ön Çalışma, Konuralp Tıp Dergisi 2012;4(3):1-11

21. Tanriverdi G, et al. Ways of Coping with Pain in The Elderly: Turkey Sample. International Journal of Caring Sciences SeptemberDecember 2013; 6(3):522-530.

22. Çetin H, Günay N, Dalak H. Traditional Practices to Women During Pregnancy, Birth and After Birth and Reasons., HealthMED 2012; 6(7): 2395-2406.

23. Falk E. Traditional Medicine, Sharing Experiences from the Field., Living Heritage Series., Republic of Korea., Seohak-Ro, Wansan-Gu, Jeonju 2017. p:3-172. 